\title{
Desain Sel Elektrolisis untuk Memproduksi MgO dari Limbah Garam Rakyat
}

\author{
Slamet Saefudin*, Sulistyo, Sulardjaka, Ryan Arfiansyah \\ Departemen Teknik Mesin, Fakultas Teknik, Universitas Diponegoro \\ J1. Prof. Soedarto, Tembalang, Semarang, Jawa Tengah \\ *E-mail: slametsaefudin66@gmail.com
}

Diterima: 08-04-2021; Direvisi: 18-07-2021; Dipublikasi: 25-08-2021

\begin{abstract}
Abstrak
Pemanfaatan magnesium oksida $(\mathrm{MgO})$ dibidang rekayasa sangat beragam maka diperlukan eksplorasi sumber bahan baku yang tersedia di alam. Limbah garam (bittern) memiliki kandungan magnesium yang cukup tinggi sehingga dapat dijadikan sebagai alternatif bahan baku pembentukan $\mathrm{MgO}$. Pembentukan $\mathrm{MgO}$ dari limbah garam dapat dilakukan dengan proses elektrolisis. Terbatasnya peralatan dan minimnya kualitas sel elektrolisis untuk memproduksi MgO dari limbah garam maka desain sel elektrolisis tersebut perlu dilakukan. Tujuan dari penelitian ini adalah mendesain alat elektrolisis yang dapat digunakan untuk pembentukan $\mathrm{MgO}$ dari limbah garam. Metodologi yang dilakukan meliputi merancang dan membuat alat elektrolisis 2 kompartemen dengan kapasitas total 0,75 liter. Proses elektrolisis dilakukan dengan variasi tegangan listrik dan variasi waktu yang berasal dari output power supply. Elektrolisis bittern akan menghasilkan endapan magnesium hidroksida $\left(\mathrm{Mg}(\mathrm{OH})_{2}\right)$ yang kemudian dikeringkan pada suhu $110{ }^{\circ} \mathrm{C}$ selama 2 jam. Serbuk hasil pengeringan pada suhu $110^{\circ} \mathrm{C}$ dipanaskan kembali pada suhu $700{ }^{\circ} \mathrm{C}$ selama 2 jam. Serbuk hasil pemanasan $700{ }^{\circ} \mathrm{C}$ dikarakterisasi dengan X-Ray Diffraction (XRD). Analisa XRD menunjukkan bahwa puncak difraksi yang terbentuk pada sudut $2 \theta$ merupakan karakteristik dari puncak - puncak difraksi senyawa MgO. Hasil karakterisasi XRD membuktikan bahwa desain alat elektrolisis dapat berfungsi dengan baik.
\end{abstract}

Kata kunci: bittern; desain; $\mathrm{MgO} ; \mathrm{Mg}(\mathrm{OH})_{2}$; sel elektrolisis

\begin{abstract}
Utilization of magnesium oxide $(\mathrm{MgO})$ in the field of engineering is very diverse, it is necessary to explore the source of raw materials available in nature. Salt waste (bittern) has a high enough magnesium content so that it can be used as an alternative raw material for the formation of $\mathrm{MgO}$. The formation of $\mathrm{MgO}$ from salt waste can be done by electrolysis process. Limited equipment and lack of quality of electrolysis cells to produce MgO from salt waste, the design of electrolysis cells needs to be done. The purpose of this study was to design an electrolysis tool that can be used for the formation of $\mathrm{MgO}$ from salt waste. Methodology includes designing and making electrolysis tools 2 compartments with a total capacity of 0.75 liters. The electrolysis process is carried out with variations in electrical voltage and time variations derived from the power supply output. Bittern electrolysis will produce a magnesium hydroxide deposit $\left(\mathrm{Mg}(\mathrm{OH})_{2}\right)$ which is then dried at $110^{\circ} \mathrm{C}$ for 2 hours. The drying powder at $110^{\circ} \mathrm{C}$ is reheated at $700^{\circ} \mathrm{C}$ for 2 hours. Powder from $700{ }^{\circ} \mathrm{C}$ heating is characterized by X-Ray Diffraction (XRD). XRD analysis showed that the diffraction peak formed at an angle of $2 \theta$ is characteristic of the peaks of $M g O$ compound diffraction. The result of XRD characterization proves that the design of electrolysis tools can function properly.
\end{abstract}

Keywords: bittern; design; electrolysis cell; $\mathrm{MgO} ; \mathrm{Mg}(\mathrm{OH})_{2}$

\section{Pendahuluan}

Air laut memiliki kandungan magnesium sekitar $3.1 \times 10^{15}$ tons [1] dan magnesium merupakan unsur terbesar ketiga dalam air laut. Air laut yang diolah menjadi kristal garam menyisakan limbah garam yang disebut bittern. Bittern memiliki kandungan magnesium yang lebih tinggi dari kandungan magnesium yang terdapat dalam air laut [2]. Kandungan magnesium yang besar ini perlu dimanfaatkan sebagai salah satu sumber bahan baku pembuatan senyawa dan logam magnesium. Kandungan magnesium dalam bittern merupakan sumber material teknik yang dapat dimanfaatkan diberbagai bidang rekayasa. Beberapa peneliti telah mencoba untuk mengubah limbah garam menjadi senyawa magnesium yang memiliki nilai ekonomis [3-6]. Dengan demikian limbah garam dapat dipakai sebagai sumber bahan baku pembentukan logam dan senyawa magnesium. Limbah garam yang dihasilkan dari proses pembentukan kristal garam dapat diolah menjadi senyawa magnesium oksida $(\mathrm{MgO})$ salah satunya dengan menggunakan proses elektrolisis [7]. 
Secara mudah elektrolisis merupakan reaksi penguraian zat dalam larutan dengan menggunakan arus listrik. Proses elektrolisis telah digunakan untuk memisahkan senyawa $\mathrm{Mg}^{+}$yang terdapat dalam air garam (brine) [8]. Proses elektrolisis dengan elektrolit air laut dan bittern akan menghasilkan senyawa magnesium hidroksida $\left(\mathrm{Mg}(\mathrm{OH})_{2}\right)$ [7]. Senyawa $\mathrm{Mg}(\mathrm{OH})_{2}$ jika dipanaskan atau dikalsinasi akan melepaskan senyawa $\mathrm{H}_{2} \mathrm{O}$ [9] dan menyisakan $\mathrm{MgO}$ [10,11] dalam bentuk padat. $\mathrm{MgO}$ merupakan senyawa magnesium yang mempunyai manfaat di berbagai bidang.

Pemanfaatan material senyawa $\mathrm{MgO}$ digunakan sebagai bahan refractory atau tungku api [12-14], bahan pembuat keramik antibakteri [15-17], bahan superconductor [18] serta bahan campuran dalam pembuatan fertilizer [19]. Senyawa $\mathrm{MgO}$ dapat pula digunakan sebagai bahan baku untuk pembentukan logam magnesium $[1,20]$. Banyaknya manfaat dari senyawa magnesium maka perlu dilakukan perancangan sebuah alat untuk memproduksi senyawa magnesium tersebut melalui proses elektrolisis. Perancangan alat elektrolisis dilakukan untuk mengoptimalkan proses pembentukan $\mathrm{MgO}$ selama proses elektrolisis berlangsung. Material yang dipilih dalam pembuatan sel elektrolisis diharapkan mampu menahan panas dan tidak mengganggu reaksi saat proses elektrolisis berlangsung.

Penelitian ini bertujuan untuk mendesain dan membuat alat elektrolisis yang mampu memproduksi $\mathrm{MgO}$ dari bahan baku bittern yang berasal dari limbah garam rakyat. Tahap awal untuk mengetahui unsur kimia yang terdapat dalam limbah bittern dilakukan karakterisasi menggunakan XRF. Perancangan alat dan komponen yang diperlukan dalam pembuatan sel elektrolisis dibahas dalam penelitian ini. Alat elektrolisis yang dirancang dan dibuat dipakai untuk mengolah limbah bittern menjadi endapan $\mathrm{Mg}(\mathrm{OH})_{2}$. Endapan $\mathrm{Mg}(\mathrm{OH})_{2}$ dari proses elektrolisis dikeringkan pada suhu $110^{\circ} \mathrm{C}$ selama $2 \mathrm{jam}$. Serbuk kering dipanaskan kembali pada suhu $700{ }^{\circ} \mathrm{C}$ selama 2 jam. Karakterisasi serbuk proses pemanasan $700{ }^{\circ} \mathrm{C}$ dilakukan dengan XRD untuk mengetahui senyawa yang terkandung didalam material hasil proses elektrolisis tersebut.

\section{Metode Penelitian}

Penelitian dimulai dengan menyiapkan komponen - komponen yang diperlukan untuk pembuatan sel elektrolisis. Beberapa komponen elektrolisis seperti power supply, elektroda, elektrolit, kompartemen, dan jembatan garam dipersiapkan terlebih dahulu. Komponen - komponen yang sudah siap kemudian dirakit menjadi alat elektrolisis seperti ditunjukkan pada Gambar 1. Penelitian dilakukan di laboratorium teknik mesin Universitas Diponegoro.

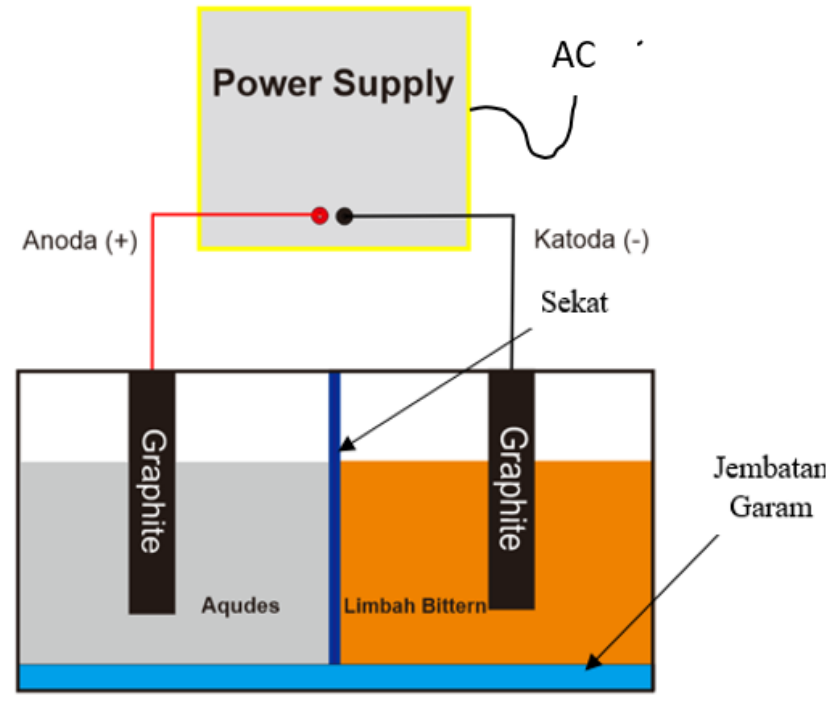

Gambar 1. Desain alat elektrolisis

Pengecekan dilakukan untuk mengetahui desain alat elektrolisis dapat berfungsi dengan baik. Uji coba dilakukan dengan mengatur output dari power supply sebesar 10, 12, 14, dan 16 Volt DC dengan arus 2 ampere selama 2 jam. 
Lamanya proses elektrolisis juga diamati dengan variasi waktu 1, 2, 3, dan 4 jam. Setelah proses elektrolisis selesai, hasil dari proses elektrolisis kemudian dikeringkan selama 2 jam pada suhu $110^{\circ} \mathrm{C}$ dan ditimbang. Hasil elektrolisis yang sudah kering kemudian dipanaskan kembali pada suhu $700{ }^{\circ} \mathrm{C}$ selama $2 \mathrm{jam}$. Analisa produk dari hasil elektrolisis dilakukan untuk mengetahui senyawa yang terbentuk dari proses elektrolisis. Analisa dilakukan dengan pengujian XRD. Analisa pola difraksi XRD dilakukan dengan menggunakan software Match 3.

\section{Hasil dan Pembahasan}

\subsection{Rancang Bangun Sel elektrolisis}

Rancang bangun dimulai dengan pembuatan kompartemen sebagai tempat dari elektrolit. Desain sel elektrolisis terdiri dari 2 buah kompartemen seperti ditunjukkan pada Gambar 1. Kompartemen anoda untuk kutub positif sedangkan kompartemen katoda untuk kutub negatif. Kompartemen dipisahkan oleh sekat untuk menghindari pencampuran elektrolit dari katoda ke anoda. Bahan baku kompartemen terbuat dari akrilik dengan tebal $2 \mathrm{~mm}$ yang dirangkai dengan cara dilem. Pemilihan bahan akrilik diharapkan dapat menahan suhu yang dihasilkan dari proses elektrolisis dan tidak mengganggu reaksi kimia yang terjadi selama proses elektrolisis. Adapun dimensi dari kompartemen ditunjukkan pada Gambar 2. Pada bagian bawah kompartemen terdapat celah dengan ukuran $8 \mathrm{~mm}$ yang digunakan sebagai tempat jembatan garam.
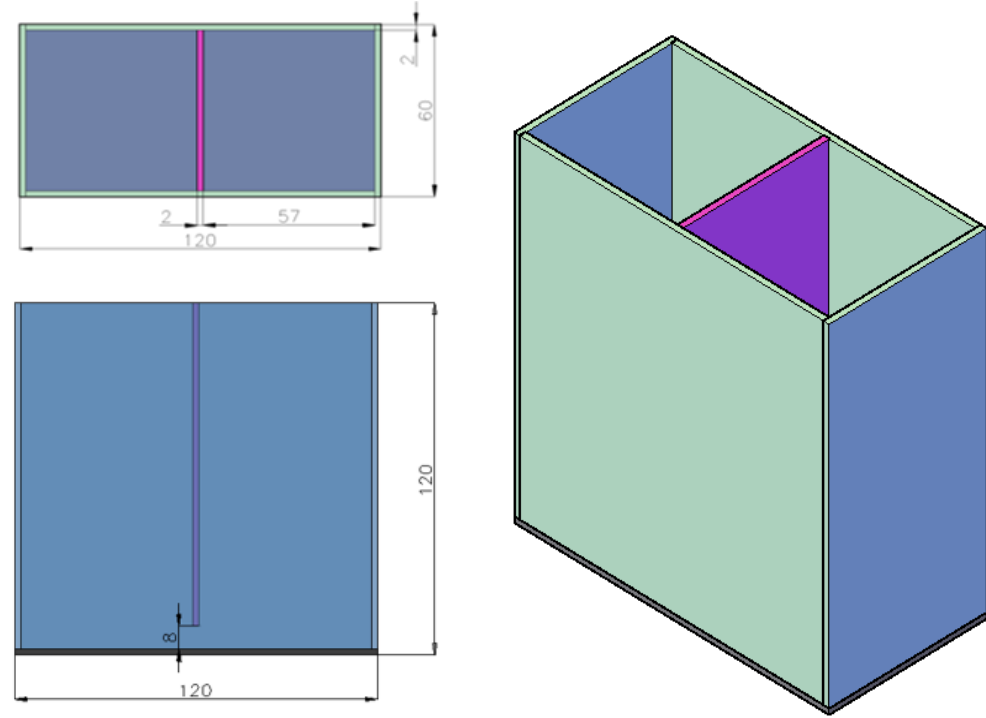

Gambar 2. Kompartemen sel elektrolisis

Jembatan garam berfungsi untuk menghubungkan kedua kompartemen yang terpisah oleh sekat sehingga proses elektrolisis dapat berlangsung. Jembatan garam terbuat dari agar - agar yang dicampur dengan garam. Sebanyak 50 gram garam dengan kandungan 99,25\% $\mathrm{NaCl}$ dicampur dengan 3,5 gram bubuk agar-agar. Campuran tersebut kemudian direbus dengan menggunakan $20 \mathrm{ml}$ aquades sampai mendidih kemudian dituangkan ke dalam kompartemen dan didiamkan sampai suhu lingkungan. Langkah selanjutnya adalah menyiapkan elektroda graphite.

Elektroda graphite berbentuk silinder dengan ukuran panjang $100 \mathrm{~mm}$ dan diameter $10 \mathrm{~mm}$. Pemilihan elektroda graphite dikarenakan elektroda ini mempunyai sifat inert yaitu tidak bereaksi saat proses elektrolisis berlangsung dan berfungsi sebagai penghantar listrik yang baik. Elektroda graphite juga tahan terhadap panas yang cukup tinggi. Elektroda dihubungkan dengan power supply menggunakan kabel penghubung. Pada proses elektrolisis elektroda akan direndam didalam elektrolit dengan kedalaman $50 \mathrm{~mm}$. 
Slamet Saefudin dkk /Jurnal Rekayasa Mesin

p-ISSN: 1411-6863, e-ISSN: 2540-7678

Vol.16|No.2|225-233|Agustus|2021

\subsection{Percobaan Elektrolisis}

Percobaan dilakukan untuk mengetahui keberhasilan peralatan elektrolisis yang telah dibuat. Sebanyak $200 \mathrm{ml}$ atau 234,25 gram limbah garam (bittern) dimasukkan ke dalam kompartemen katodik dan $200 \mathrm{ml}$ aquades ke dalam kompartemen anodik. Limbah garam yang merupakan bahan baku $\mathrm{MgO}$ berperan sebagai elektrolit dalam proses elektrolisis. Limbah garam terlebih dahulu dikarakterisasi dengan uji komposisi untuk mengetahui kandungan unsur magnesium yang terdapat dalam limbah tersebut. Karakterisasi uji komposisi dilakukan menggunakan pengujian XRF dengan hasil tiga unsur utama limbah garam adalah: 5,446 \% $\mathrm{Na}, 10,277 \% \mathrm{Cl}$, dan 1,1588\% $\mathrm{Mg}$.

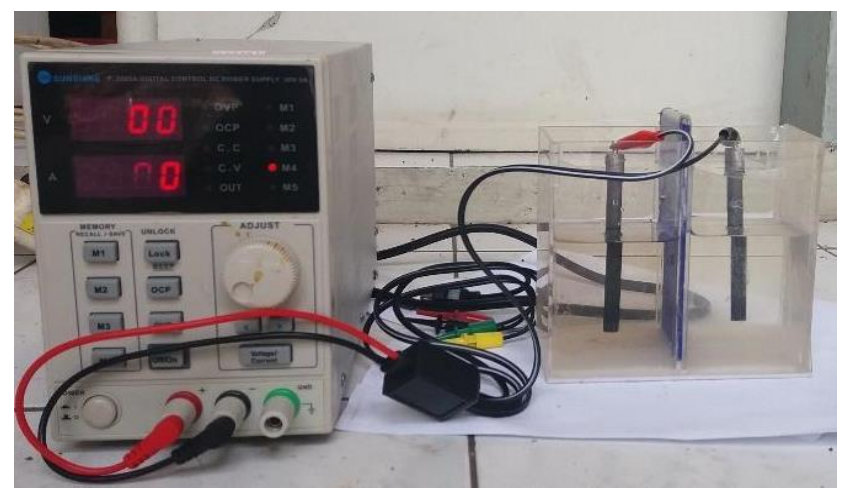

Gambar 3. Percobaan elektrolisis

Percobaan elektrolisis seperti ditunjukkan pada Gambar 3. Power supply dihubungkan ke sumber arus listrik AC kemudian diatur keluaran tegangan DC sebesar 10,12,14 dan 16 Volt dengan arus maksimal 2 ampere. Keluaran dari power supply diteruskan ke elektroda katoda dan anoda dengan kabel penghubung. Pengaruh tegangan listrik dan perubahan arus selama proses elektrolisis diamati setiap 15 menit selama 2 jam.

Selama proses elektrolisis ion $\mathrm{Mg}^{+}$yang terdapat dalam limbah garam akan saling berikatan dengan ion $\mathrm{OH}^{-}$yang bermuatan negatif. Persamaan reaksi yang terjadi dalam proses elektrolisis dapat dituliskan sebagai berikut:

$2 \mathrm{H}_{2} \mathrm{O}_{(\mathrm{l})}+2 \mathrm{e} \rightarrow{ }^{-} \mathrm{H}_{2(\mathrm{~g})}+2 \mathrm{OH}^{-}(\mathrm{aq})$

Anoda :

$2 \mathrm{Cl}^{-}(\mathrm{aq}) \rightarrow \mathrm{Cl}_{2(\mathrm{~g})}+2 \mathrm{e}^{-}$

Sedangkan pembentukan $\mathrm{Mg}(\mathrm{OH})_{2}$ terjadi dengan reaksi :

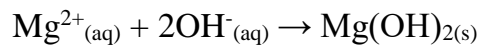

Berdasarkan persamaan 3 maka dapat dipastikan bahwa proses elektrolisis limbah garam akan menghasilkan senyawa $\mathrm{Mg}(\mathrm{OH})_{2}$ dalam bentuk padatan. Pembentukan $\mathrm{Mg}(\mathrm{OH})_{2}$ ini akan terjadi pada kompartemen katoda yang bermuatan negatif.

Gambar 4 menunjukkan bahwa terdapat pengaruh tegangan listrik terhadap $\operatorname{Mg}(\mathrm{OH})_{2}$ yang dihasilkan dari proses elektrolisis. Selama proses elektrolisis, arus listrik secara perlahan akan mengalami kenaikan menuju arus keluaran maksimal 2 Ampere. Elektrolisis dilakukan selama 2 jam dengan variasi besaran tegangan listrik yang digunakan yaitu 10,12,14, dan 16 Volt. Semakin besar tegangan listrik yang digunakan maka rendemen $\mathrm{Mg}(\mathrm{OH})_{2}$ yang dihasilkan semakin banyak. Hal ini disebabkan karena besarnya tegangan listrik akan menyebabkan peningkatan jumlah arus listrik. Semakin banyak arus listrik yang digunakan maka reaksi pada persamaan (1) akan semakin besar sehingga senyawa $2 \mathrm{OH}^{-}$akan terbentuk. Adanya senyawa $2 \mathrm{OH}^{-}$maka reaksi pembentukan $\mathrm{Mg}(\mathrm{OH})_{2}$ pada persamaan (3) akan berlangsung. Banyaknya massa $\mathrm{Mg}(\mathrm{OH})_{2}$ yang dihasilkan berbanding lurus dengan banyaknya arus listrik yang digunakan sesuai dengan hukum faraday 1 [21]. Selain tegangan listrik, lamanya proses elektrolisis yang digunakan juga berpengaruh pada jumlah $\mathrm{Mg}(\mathrm{OH})_{2}$ 
Slamet Saefudin dkk /Jurnal Rekayasa Mesin

p-ISSN: 1411-6863, e-ISSN: 2540-7678

Vol.16|No.2|225-233|Agustus|2021

yang dihasilkan. Semakin lama proses elektrolisis berlangsung maka semakin banyak jumlah elektron yang dibutuhkan agar reaksi kimia dalam proses elektrolisis dapat berlangsung [22]. Banyaknya jumlah elektron bergantung pada banyaknya jumlah arus listrik. Pengaruh waktu terhadap pembentukan $\mathrm{Mg}(\mathrm{OH})_{2}$ seperti ditunjukkan pada Gambar 5 .

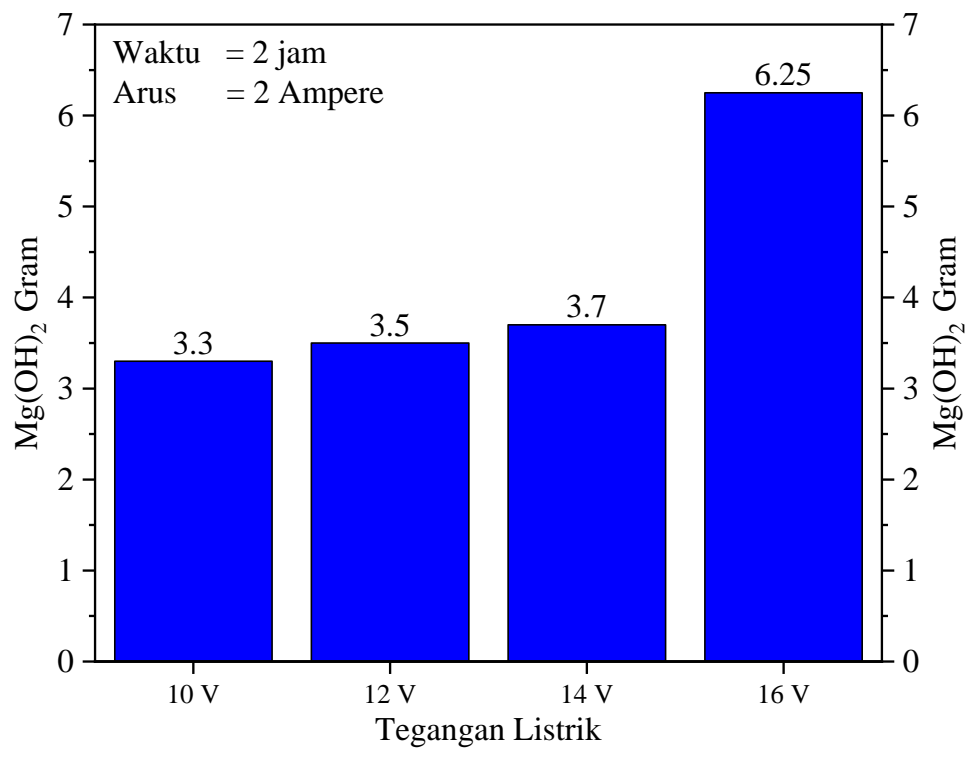

Gambar 4. Hubungan antara Tegangan listrik terhadap $\mathrm{Mg}(\mathrm{OH})_{2}$ yang dihasilkan

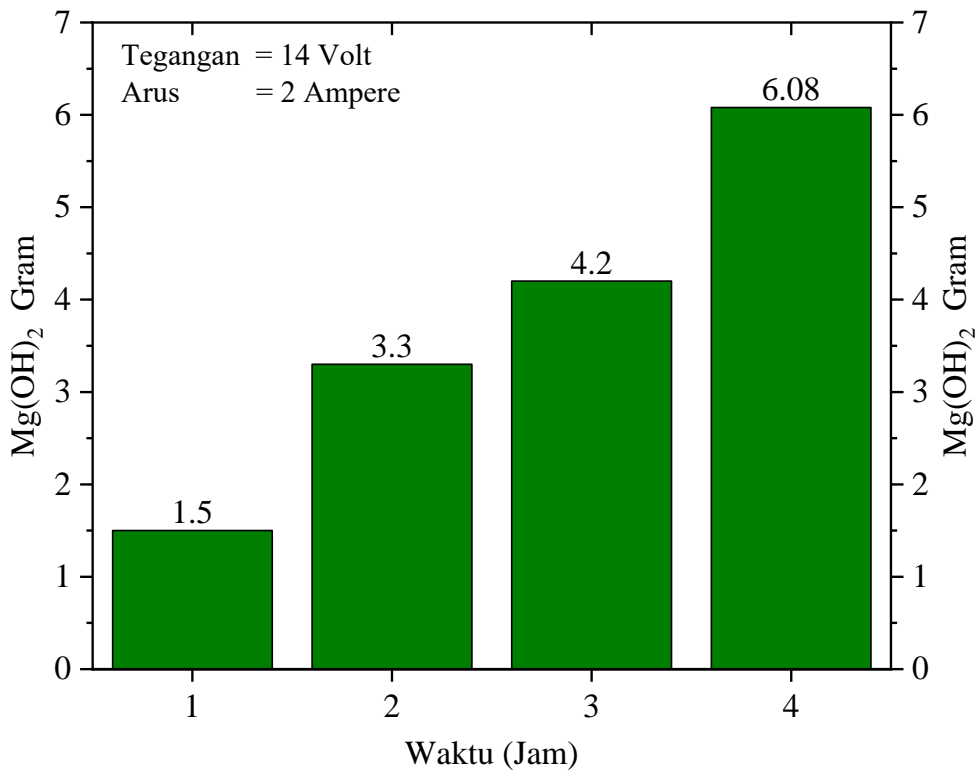

Gambar 5. Pengaruh waktu terhadap jumlah $\mathrm{Mg}(\mathrm{OH})_{2}$
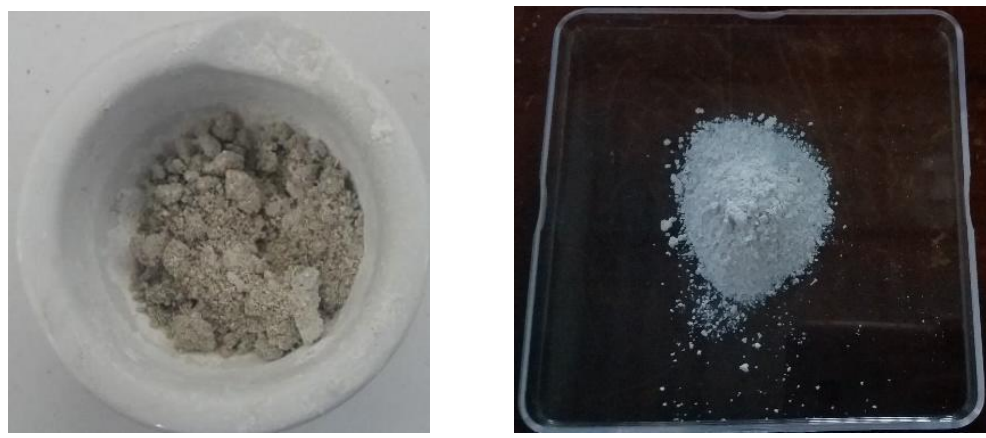

Gambar 6. Hasil elektrolisis yang telah dipanaskan selama 2 jam dengan suhu $110^{\circ} \mathrm{C}$ (kiri), $700{ }^{\circ} \mathrm{C}$ (kanan) 
Proses elektrolisis yang berlangsung belum dapat merubah ion $\mathrm{Mg}^{+}$menjadi $\mathrm{Mg}(\mathrm{OH})_{2}$ secara keseluruhan. Seperti ditunjukkan pada Gambar 7 dan Gambar 8, semakin besar tegangan listrik dan lamanya waktu yang diperlukan untuk proses elektrolisis akan meningkatkan persentase pembentukan ion $\mathrm{Mg}^{+}$menjadi $\mathrm{Mg}(\mathrm{OH})_{2}$. Prosentase ini dihitung dari unsur $\mathrm{Mg}$ yang terkandung dalam bittern melalui pengujian XRF yaitu 1,1588\% Mg tiap 100 gram bittern. Berat bittern yang digunakan dalam setiap proses elektrolisis adalah 234,25 gram sehingga didapat berat senyawa $\mathrm{Mg}(\mathrm{OH})_{2}$ dalam bittern adalah 6,559 gram. Proses elektrolisis pada tegangan 16 Volt selama 2 jam menghasilkan 6,25 gram $\mathrm{Mg}(\mathrm{OH})_{2}$ sehingga persentase perubahan ion $\mathrm{Mg}^{+} \mathrm{ke} \mathrm{Mg}(\mathrm{OH})_{2}$ adalah 95,28\%. Variasi waktu tertinggi menghasilkan $\mathrm{Mg}(\mathrm{OH})_{2}$ paling tinggi sebesar 6,08 gram sehingga persentase perubahannya adalah 92,69\%. Persentase perubahan $\mathrm{Mg}$ menjadi $\mathrm{Mg}(\mathrm{OH})_{2}$ selain dipengaruhi oleh tegangan dan arus listrik juga dipengaruhi oleh banyaknya campuran senyawa yang terdapat dalam larutan limbah garam yang tidak homogen [23]. Hasil dari $\mathrm{Mg}(\mathrm{OH})_{2}$ yang didapat dari proses elektrolisis seperti ditunjukkan pada gambar 6.

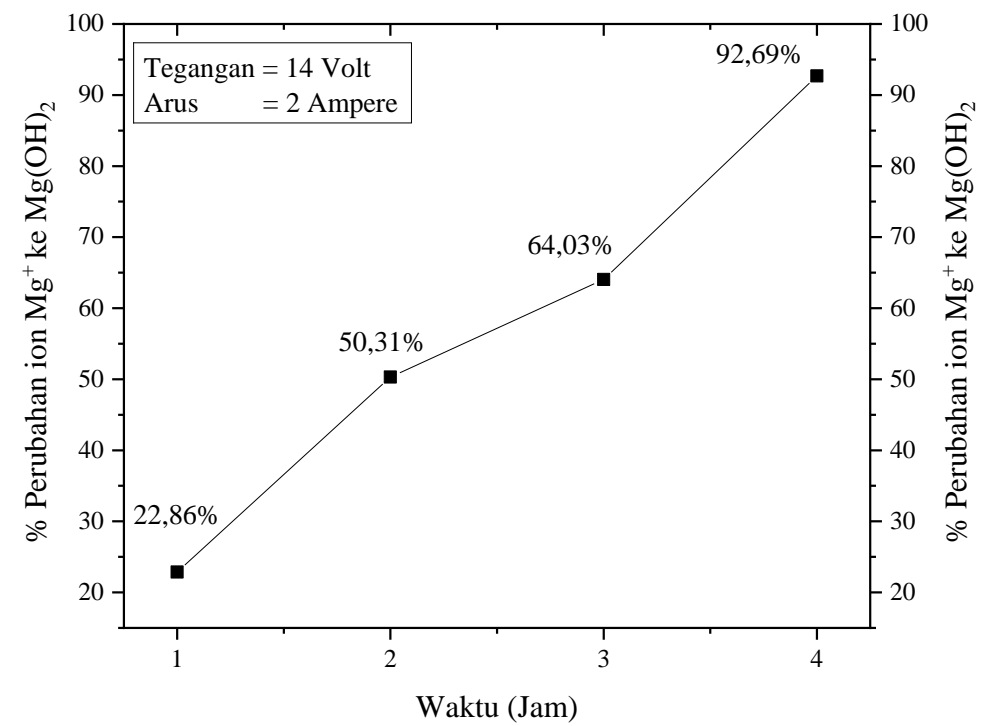

Gambar 7. Pengaruh waktu terhadap persentase perubahan ion $\mathrm{Mg}^{+}$menjadi $\mathrm{Mg}(\mathrm{OH})_{2}$

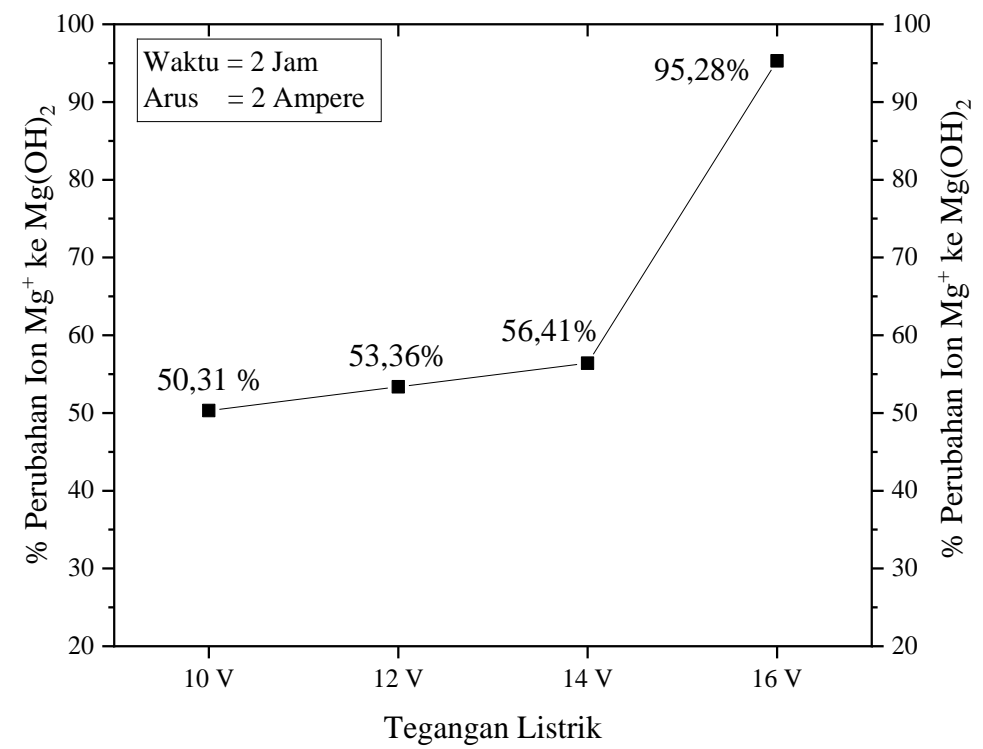

Gambar 8. Pengaruh tegangan listrik terhadap persentase perubahan ion $\mathrm{Mg}^{+}$menjadi $\mathrm{Mg}(\mathrm{OH})_{2}$ 


\subsection{Analisa Produk Hasil Elektrolisis}

Analisa pola difraksi sinar - X dilakukan dengan menggunakan XRD. Pola difraksi tersebut kemudian dianalisis dengan menggunakan software Match 3 dan dibandingkan dengan data JCPDS MgO. Hasil analisa seperti ditunjukkan pada Gambar 9. Perbandingan data JCPDS $\mathrm{MgO}$ dengan sampel $\mathrm{MgO}$ yang telah dihasilkan seperti pada gambar 9 menunjukkan adanya kemiripan puncak yang terbentuk pada sudut $2 \theta: 36,862,42,824,62,167,74,515$ dan 78,443 yang merupakan karakteristik dari senyawa $\mathrm{MgO}$. Hal tersebut diperkuat dengan terdapatnya dua puncak dengan intensitas paling tinggi yaitu pada sudut $2 \theta: 42,824$ dan 62,167 . Hasil analisa XRD sampel produk elektrolisis juga sesuai dengan pola difraksi MgO hasil penelitian Nemada \& Waghuley [24].

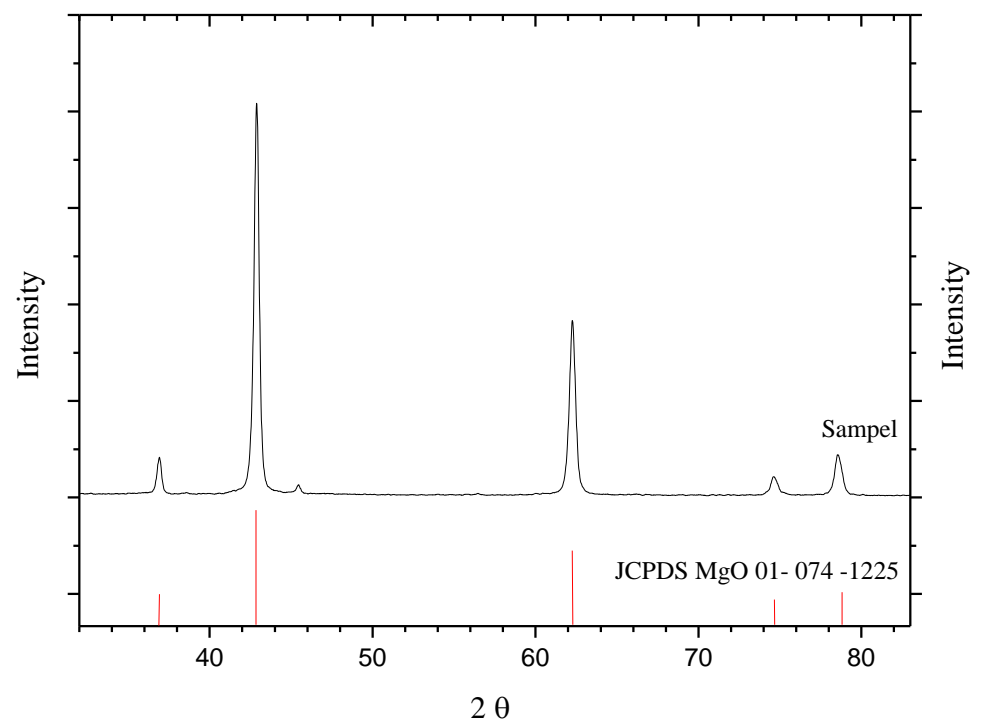

Gambar 9. Analisa pola difraksi XRD pada sampel hasil elektrolisis

\section{Kesimpulan}

Penelitian ini mengkaji sebuah desain sel elektrolisis untuk memproduksi $\mathrm{MgO}$ dari limbah garam rakyat. Komponen - komponen sel elektrolisis didesain menjadi sebuah alat elektrolisis. Uji coba terhadap alat elektrolisis telah dilakukan. Sebanyak $200 \mathrm{ml}$ limbah garam diperoleh $\mathrm{Mg}(\mathrm{OH})_{2}$ kering sebanyak 6,25 gram pada tegangan 16 Volt dengan proses elektrolisis selama 2 jam. Besarnya daya listrik serta waktu proses elektrolisis sangat mempengaruhi jumlah $\mathrm{Mg}(\mathrm{OH})_{2}$ yang dihasilkan selama proses elektrolisis. Terbukti bahwa jumlah rendemen yang dihasilkan paling banyak pada elektrolisis yang dilakukan selama 4 jam dengan hasil $\mathrm{Mg}(\mathrm{OH})_{2}$ yaitu 6,08 gram. Persentase perubahan ion $\mathrm{Mg}^{+}$menjadi $\mathrm{Mg}(\mathrm{OH})_{2}$ yaitu $95,28 \%$ pada tegangan 16 Volt. Hasil analisa difraksi sinar-X dengan menggunakan XRD membuktikan bahwa senyawa yang terbentuk adalah $\mathrm{MgO}$ dengan ciri spesifik memiliki lima puncak utama dengan dua puncak yang memiliki intensitas tertinggi pada sudut $2 \theta: 42,824$ dan 62,167. Hasil penelitian membuktikan bahwa desain sel elektrolisis mampu memproduksi $\mathrm{MgO}$ dari limbah garam dan desain sel elektrolisis dapat dikembangkan dalam skala yang lebih besar.

\section{Daftar Pustaka}

[1] Neelameggham R. Primary production of magnesium. Fundam. Magnes. Alloy Metall., Elsevier; 2013, p. 1-32. https://doi.org/10.1533/9780857097293.1.

[2] Wada S, Iijima J, Takiyama H. Crystallization Operation Method for Recovering Mg Resources from the Sea Water Desalination Process. J Chem Eng Japan 2015;48:94-8. https://doi.org/10.1252/jcej.14we157.

[3] Femitha RD, Vaithyanathan C. Preparation of Magnesium Hydroxide Nanoparticles From Bittern. Green Chem Technol Lett 2016. https://doi.org/10.18510/gctl.2016.227. 
[4] Sanghavi RJ, Dobariya R, Bhatti S, Kumar A. Preparation of high-purity magnesium-ammonium-phosphate fertilizer using sea bittern and industrial waste streams. Environ Sci Pollut Res. 2020; 27: 7720-8. https://doi.org/10.1007/s11356-019-07445-4.

[5] Sibak HA, El-Rafie SA, El-Sherbini SA, Osman RM, Said M, Ramadan R. Kinetic study of Nano-Magnesium oxalate precipitated from bittern. ARPN J Eng Appl Sci. 2018.

[6] Park JW, Lee WK, Lee CH. Morphology control of magnesium oxide nanoparticles from seawater bittern using a wet decarboxylation/precipitation method. Mol Cryst Liq Cryst. 2017; 654: p. 96-102. https://doi.org/10.1080/15421406.2017.1355710.

[7] Amrulloh H, Simanjuntak W, Situmeang RTM, Sagala SL, Bramawanto R, Fatiqin A, et al. Preparation of nanomagnesium oxide from Indonesia local seawater bittern using the electrochemical method. Inorg Nano-Metal Chem. 2020. https://doi.org/10.1080/24701556.2020.1724146.

[8] Díaz Nieto CH, Palacios NA, Verbeeck K, Prévoteau A, Rabaey K, Flexer V. Membrane electrolysis for the removal of $\mathrm{Mg} 2+$ and $\mathrm{Ca} 2+$ from lithium rich brines. Water Res. 2019; 154: p. 117-24. https://doi.org/10.1016/j.watres.2019.01.050.

[9] Pilarska AA, Klapiszewski Ł, Jesionowski T. Recent development in the synthesis, modification and application of $\mathrm{Mg}(\mathrm{OH}) 2$ and $\mathrm{MgO}$ : A review. Powder Technol 2017;3 19: p. 373-407. https://doi.org/10.1016/j.powtec. 2017.07.009.

[10] Henrist C, Mathieu J-P, Vogels C, Rulmont A, Cloots R. Morphological study of magnesium hydroxide nanoparticles precipitated in dilute aqueous solution. J Cryst Growth. 2003; 249: p. 321-30. https://doi.org/10.1016/S0022-0248(02)02068-7.

[11] Lv J, Qiu L, Qu B. Controlled growth of three morphological structures of magnesium hydroxide nanoparticles by wet precipitation method. J Cryst Growth. 2004; 267: p. 676-84. https://doi.org/10.1016/j.jcrysgro.2004.04.034.

[12] Gheisari Dehsheikh H, Ghasemi-Kahrizsangi S. Performance improvement of MgO-C refractory bricks by the addition of Nano-ZrSiO4. Mater Chem Phys. 2017; 202: p. 369-76. https://doi.org/10.1016/j.matchemphys.2017.09.055.

[13] Zhu T, Li Y, Sang S, Xie Z. Fracture behavior of low carbon MgO-C refractories using the wedge splitting test. J Eur Ceram Soc 2017;37:1789-97. https://doi.org/10.1016/j.jeurceramsoc.2016.11.013.

[14] Gu Q, Zhao F, Liu X, Jia Q. Preparation and thermal shock behavior of nanoscale MgAl2O4 spinel-toughened MgO-based refractory aggregates. Ceram Int. 2019; 45: p. 12093-100. https://doi.org/10.1016/j.ceramint.2019.03.107.

[15] Maji J, Pandey S, Basu S. Synthesis and evaluation of antibacterial properties of magnesium oxide nanoparticles. Bull Mater Sci. 2020; 43: p. 25. https://doi.org/10.1007/s12034-019-1963-5.

[16] Umaralikhan L, Jamal Mohamed Jaffar M. Green Synthesis of MgO Nanoparticles and it Antibacterial Activity. Iran J Sci Technol Trans A Sci. 2018; 42: p. 477-85. https://doi.org/10.1007/s40995-016-0041-8.

[17] Hikku GS, K. J, Vignesh Kumar S. Nanoporous $\mathrm{MgO}$ as self-cleaning and anti-bacterial pigment for alkyd based coating. J Ind Eng Chem 2017;52:168-78. https://doi.org/10.1016/j.jiec.2017.03.040.

[18] Shiogai J, Ito $\mathrm{Y}$, Mitsuhashi $\mathrm{T}$, Nojima $\mathrm{T}$, Tsukazaki A. Electric-field-induced superconductivity in electrochemically etched ultrathin FeSe films on $\mathrm{SrTiO} 3$ and $\mathrm{MgO}$. Nat Phys. 2016. https://doi.org/10.1038/nphys3530.

[19] Purnama Putra H, Pandu Mursanto B, Handayani A. Utilization of Human Urine as Fertilizer with Magnesium 
Oxide (MgO), Zeolite and Activated Carbon as Absorbent. Int J Adv Sci Eng Inf Technol. 2014; 4: p. 173. https://doi.org/10.18517/ijaseit.4.3.395.

[20] Martínez AM, Børresen B, Haarberg GM, Castrillejo Y, Tunold R. Electrodeposition of Magnesium from CaCl[sub 2]-NaCl-KCl-MgCl[sub 2] Melts. J Electrochem Soc. 2004; 151: C508. https://doi.org/10.1149/1.1758814.

[21] Goodridge F, Scott K. Electrochemical Process Engineering. 1st ed. Boston, MA: Springer US; 1995. https://doi.org/10.1007/978-1-4899-0224-5.

[22] Topayung D. Effect of Electric Current and Process Time in The Thickness and Mass Layer Formed on Electroplating Steel Plates. J Ilm Sains. 2011; 11: p. 97-101.

[23] Buyang Y, Asmaraningrum HP. Pengaruh Voltase Dan Waktu Terhadap Tembaga Menggunakan Metode Elektroplating. Magistra. 2015; 2: 226-36.

[24] Nemade KR, Waghuley SA. Synthesis of MgO Nanoparticles by Solvent Mixed Spray Pyrolysis Technique for Optical Investigation. Int J Met. 2014; 2014: p. 1-4. https://doi.org/10.1155/2014/389416. 